University of Nebraska - Lincoln

DigitalCommons@University of Nebraska - Lincoln

May 1995

\title{
From Marx to Markets: Reform of the University Economics Curriculum in Russia
}

Stanley L. Brue

Pacific Lutheran University

Craig MacPhee

University of Nebraska-Lincoln, cmacphee1@unl.edu

Follow this and additional works at: https://digitalcommons.unl.edu/econfacpub

Part of the Economics Commons

Brue, Stanley L. and MacPhee, Craig, "From Marx to Markets: Reform of the University Economics Curriculum in Russia" (1995). Economics Department Faculty Publications. 21.

https://digitalcommons.unl.edu/econfacpub/21

This Article is brought to you for free and open access by the Economics Department at DigitalCommons@University of Nebraska - Lincoln. It has been accepted for inclusion in Economics Department Faculty Publications by an authorized administrator of DigitalCommons@University of Nebraska - Lincoln. 


\section{From Marx to Markets: Reform of the University Economics Curriculum in Russia}

\section{Stanley L. Brue and Craig R. MacPhee}

In June 1992, we taught a three-week seminar at Moscow State University that coincided with the beginning of a historic curriculum reform in Russia. ${ }^{1}$ The reform had two parts: (1) the replacement of the Marxist-Leninist three-year sequence of courses in political economy with a sequence on market economics and (2) substantial revision of other course requirements for the economics degree.

The occasion of our Russian visit was an invitation from Moscow State University to present a seminar on the principles of market economics. The seminar demonstrated the typical content and teaching techniques used in the American micro-macro principles course. Our efforts were greatly facilitated by simultaneous translation of our lectures and discussions, although problems with Russian equivalents for precise economic terminology in English occasionally presented difficulties. ${ }^{2}$ About 70 professors from throughout the former Soviet Union attended the seminar; most of these professors are now teaching principles of market economics in Russia.

The seminar was held in conjunction with the publication of the Russianlanguage edition of a standard American principles of economics textbook (McConnell and Brue 1990), which was the main resource for the professors taking the course. Eight Russian economists spent two years translating the McConnell and Brue textbook, working under the direction of Anatoly Porokhovsky, professor of economics at Moscow State University (MSU) and deputy director of the Institute of United States and Canada in the Russian Academy of Sciences. In 1992, Politizdat Press (now Respublika), formerly the main publishing house of the Communist Party, published 500,000 copies of this book in micro and macro volumes. Beginning with the 1992-1993 academic year, these volumes became the central textbooks for introductory economics courses at institutes and universities throughout Russia. ${ }^{3}$

It is ironic that one of the last acts of the Communist government in the former Soviet Union was official approval for the translation, publication, and employment of a basic textbook on market economics. Historically, the Ministry of Education exercised control over textbooks, and all authorships were assigned by those in positions of authority. Only two or three officially sanctioned textbooks

Stanley L. Brue is a professor of economics at Pacific Lutheran University, Craig R. MacPhee is a professor of economics at the University of Nebraska-Lincoln. The authors thank Elena Palei, Lev Palei, and Oksana Shishkova for translations and other research assistance, as well as Anatoly Porokhovsky, Sergei Dunaev, Olga Tretyak, and the referees for helpful comments. 
have been available for the beginning course in political economy. In the 1983-86 period, the Ministry of Education established an unprecedented open competition for a new political economy textbook, but none of the manuscripts submitted met the requirements of Gorbachev's glasnost and perestroika. The ministry then appointed a committee of prominent economists to write a new text. But the final product, published in 1988 , was clearly a political compromise: it contained much of the old political economy of socialism, with a more modern, favorable treatment of certain aspects of capitalism (Sutela 1991, 113). It was at this point that Porokhovsky received permission to organize the translation of a new textbook for the introductory university economics course.

Our goals in this article are twofold. First, we want to contrast the old and new Russian curricula to demonstrate the truly remarkable recent changes. Second, we assess the pitfalls and possibilities relating to the nascent curriculum reform. Our discussion throughout will focus on economics at Moscow State University, Russia's most prestigious institution of higher learning. ${ }^{4}$ The centralization of education decisions and the importance of uniformity mean that almost all Russian universities mimic the Moscow State University program.

\section{HISTORICAL BACKGROUND OF THE PRE-1992 ECONOMICS CURRICULUM}

As noted in detail by Judy (1960) and summarized by Blodgett and Schnitzer (1965), in the 1950s and 1960s, all members of the economics faculty at Moscow State University belonged to one of seven semi-independent kafederi (chairs or departments). In 1960, these chairs were Accounting and Analysis of the Economic Activity of Socialist Enterprises, Economics of Industrial Planning, Economics of Agriculture, Economies of Foreign Countries, Soviet Economic History and History of Thought, Political Economy, and Statistics. Although expanded, this system of kafederi remains at Moscow State University today.

From the 1960s through the 1980s, the courses offered by these kafederi made up the study of socialist political economy. The courses were confined to the detailed analysis of the works of Marx and Lenin, the application of their ideas to specific sectors of the economy, and the criticisms of other economies and other economic theories. The Seven-Year Plan of 1959-1965 helps describe the content of the political economy of socialism during this period, and for that matter, for the decades that followed. The plan assigned several research topics to the economics faculty, including Laws of Development in Socialist Society, Criticisms of Contemporary Bourgeois Political Economy and the Struggle with Revisionism of Economic Theory in the Contemporary Period, and The Further Strengthening and Development of Kolkhoz [collective farm] Production. The Seven-Year Plan of 1959-1965 also established that 12 economics textbooks were to be produced. Among them were a textbook on political economy and a study aid to Marx's Capital (Blodgett and Schnitzer 1965, 4).

A new branch of economics began to emerge in the 1950 s as an adjunct and rival to political economy. Based on the work of Leonid Kantorovich and other prominent scholars, a new kafederi of mathematical economics-more specifi- 
cally, the System of Optimally Functioning Socialist Economy (SOFE) - came to the fore. This new economics, called economic cybernetics by many Russians, focused on linear programming and related optimization techniques of production. ${ }^{5}$ In 1963, the Soviet government sanctioned the founding of the Central Economic-Mathematical Institute of the Soviet Academy of Sciences, which established the journal Economy and Mathematical Methods. The Soviet cybernetics was the mathematical economics of central planning and state enterprise, and it did not analyze the behavior of consumers, producers, and traders in response to market signals. Optimization always referred to the objective functions established at the highest level of government (Sutela 1991 chapts. 1 and 2).

Thus, two different economics degrees came to coexist within the economics programs at the major Russian universities. ${ }^{6}$ The Political Economy of Socialism focused on the works of Marx and Lenin. It was historical and heavily ideological, with research consisting of papers loaded with citations of Marx, Lenin, and current leaders of the Communist Party. On the other hand, SOFE was highly mathematical, aimed at developing methods for implementing the long-run plans and improving the operation of state enterprises. Because the methodologies of these approaches differ, much tension has arisen between adherents of the two subdisciplines. As we experienced in our seminar, where the political economists were in the majority, these tensions remain today. ${ }^{\text {? }}$

Neither the Russian political economists nor the mathematical economists should be confused with typical American economists. Alexeev, Gaddy, and Leitzel (1992), for example, have asserted that political economists in Russia have more in common with American sociologists than with American economists. It is equally true that many Russian mathematical economists have more in common with American specialists in operations research than with typical economists. Nevertheless, as market economics spreads through the Russian curriculum, Russian economics is becoming more like that taught in the West.

\section{THE CURRICULUM IN RUSSIA IN THE LATE 1980s}

To place the recent changes in perspective, we examine the typical Russian curriculum in political economy before 1992. Substantial overlap of the political economy and cybernetics curricula allows us to avoid repetition and to save space. The main differences between the political economy and cybernetics curricula lay in the extent of formal mathematics and applied mathematics courses. ${ }^{8} \mathrm{~A} 5$-year degree program divided into 4.5 years ( 9 semesters) of course work and a 10th semester for senior thesis writing and an internship is summarized in Table 1. The internships usually complemented a student's specialization, for example, an agricultural economist interned at a collective farm.

In a pattern more familiar to Europe than to America, economics majors take almost all their courses (even language courses) within the College of Economics. As in Europe, students receive their general or liberal education in high school, so they can concentrate on their major in the university. An important exception to this rule is that all Russian university students are required to take political 
TABLE 1

Russian Political Economy Curriculum, Pre-1992

General courses

1. Political economy

a. Precapitalist modes of production and general fundamentals of capitalism (1st yr.) (212)

b. Monopolistic capitalism-imperialism ( $2 \mathrm{~d}$ yr.) (68)

c. Socialism ( $3 \mathrm{~d}$ yr.) (136)

2. History of Soviet Union (176)

3. Marxist-Leninist philosophy (244)

4. Scientific communism (140)

5. Scientific atheism (24)

6. Economic history of capitalist countries (54)

7. Economic history of socialist countries (50)

8. Economies of foreign countries (54)

9. History of economic theories (220)

10. Soviet legislation (36)

11. Industrial economics (90)

12. Agricultural economics (18)

13. Nonproductive spheres of the economy (54)

14. National economic planning (124)

15. Statistics

a. Theoretical and mathematical statistics (104)

b. Economic statistics (140)

16. Accounting (40)

17. Enterprise activity analysis (70)

18. Mathematical methods of economic analysis (54)

19. Mathematics
a. Mathematical analysis (140)
b. Linear algebra (104)
c. Mathematical programming (50)
d. Theory of probability (56)

20. Data processing (84)

21. Foreign language (400)

22. Methods of lecturing on political economy (64)

23. Psychology (36)

24. Physical training (140)

Required special seminars

25. Marx's Capital (190)

26. The theory of imperialism (100)

27. Political economy of socialism (130)

Required special courses

28. Criticism of modern bourgeois political economy (30)

29. Demography (32)

30. Labor economics (32)

31. Finance and credit (30)

32. Management of the national economy (68)

33. Economics of natural resource usage (32)

Electives

34. Improvement of economic mechanisms (14)

35. Regional management (72)

36. Economic criteria of developed socialism and problems of improving the production relations during its initial stage (32)

37. Management of scientific and technical progress (32)

(Continued on next page) 
38. Methodological problems of development of systems and categories of political economy of socialism (32)

39. Utilization of technological innovations and economic development (15)

40. Development of socialist production management theory (15)

41. Undergraduate theses: $2 \mathrm{~d}$ year; $3 \mathrm{~d}$ year; 4 th year

Practice

42. Internship

43. Diploma thesis

State exams passed

44. Scientific communism

45. Political economy

Notes: Summary translation of a student transcript from Moscow State University, 1989. Number of class hours are shown in parentheses.

economy. A few of the political economy professors in our seminar were in a service department that taught students in other colleges.

Other aspects of Russian higher education reveal less concern for intellectual diversity than in the United States. For instance, each Russian university usually recruits its faculty from its own successful graduate students. In contrast to the few specific course requirements in most American undergraduate economics programs, about three-fourths of the Russian curriculum in Table 1 consisted of specifically required courses.

Both political economy and cybernetics majors were required to take the threeyear sequence in political economy. As suggested by the titles in Table 1, these courses are based on Marxist-Leninist ideology, a fact that we document below. Several other courses in the curriculum, including Marxist-Leninist Philosophy, Scientific Atheism, History of Economic Theories, and Criticism of Modern Bourgeois Political Economy, also were ideological in nature. Both programs required students to take three advanced seminars: Marx's Capital, The Theory of Imperialism, and Political Economy of Socialism. Finally, all students had to take state exams in scientific communism and political economy. Thus, students had to study Marx and Lenin repeatedly over several years in the political economy courses, in the special seminars, and in preparation for the state exams.

\section{THE THREE-COURSE SEQUENCE IN POLITICAL ECONOMY, PRE-1992}

The topical structure of the first political economy course followed Marx's Capital almost exactly, the first seven topics covered in volume 1 of Capital, topics 8 and 9 in volume 2, and topics $10-14$ in volume 3 (Table 2). The required readings list (not shown) for this course included five works by Marx, one each by Engels and Gorbachev, and two publications from the 27th Congress and Ple- 
TABLE 2

Russian Political Economy Sequence, Pre-1992, Moscow State University: Topics

First year: Political economy: Precapitalist modes of production and general fundamentals of capitalism

1. The subject of political economy and the main features of its method (2)

2. Precapitalist formations (1)

3. Commodities and money (3)

4. The transformation of money into capital (1)

5. Production of surplus value as the law of development of capitalist production (4)

6. Wages (1)

7. Process of capital accumulation. The general law of capitalist accumulation (2)

8. The circuit of industrial capital (2)

9. The reproduction and circulation of the aggregate social capital (2)

10. Profit and the cost of production. The law of the tendency of the rate of profit to fall (4)

11. Commercial capital and commercial profit (1)

12. Interest-bearing capital, the credit system, and money circulation under capitalism (3)

13. Ground rent. Agrarian relationships under capitalism (1)

14. Revenues and their sources. National income under capitalism (1)

15. Economic crisis (1)

Second year: Monopolistic capitalism-imperialism

1. Concentration of production and monopolies (4)

2. Finance capital and the financial oligarchy (1)

3. State-monopoly capitalism (3)

4. Relationships between labor and capital under the conditions of modern capitalism (5)

5. The system of world dominance of the financial capital. World capitalist economy (5)

6. Reproduction of the social capital under the conditions of the scientific-technical revolution (2)

7. The historical place of imperialism. The general crisis of capitalism (1)

Third year: Political economy of socialism

1. Economic laws of the growing socialism. Stages of the development of the communist mode of production (2)

2. Social ownership of the means of production as the base of the socialist economic system (2)

3. Planning of socialist production. The law of planned development (2)

4. The main production relationship of socialism. The main economic laws (2)

5. Results and expenditures of socialist production. Effectiveness of production (2)

6. Commodity-Money relationships. The law of value under socialism (2)

7. Distribution relationships and achievement of social justice (2)

8. Agrarian relationships in a socialist society (2)

9. Socialist extended reproduction: the main features and advantages (2)

10. Accountability and efficiency of enterprises (2)

11. Incomes of fully-accountable enterprises: content, structure, and distribution

12. Planned pricing (1)

13. Economic mechanism of socialism: content, structure, improvement (1)

14. Economic relations between the socialist countries of world (1)

15. Acceleration of the social-economic development and communist perspective (1)

Note: Numbers in parentheses are number of seminars.

num of the Communist Party of the Soviet Union. Two textbooks on political economy were on the required reading list and were used in all three years of the sequence. One of the textbooks (Tsagolov 1973) - still in use in 1990-was last revised in 1973; the other textbook (Rumyantsev 1985) was last revised in 1985. Students, especially at Moscow State University, were required to read the original works of Marx and Lenin, not just the textbooks. 
The second year in the three-course political economy sequence (Monopolistic Capitalism-Imperialism in Table 2) was taught by professors who were the most proficient in reading English, and they covered the major Western strains of economic thought, such as marginalism, Paretian optimality, and Walrasian general equilibrium. The emphasis of this two-semester course, however, was the contrast between the naiveté of the perfectly competitive market model and the harsh "reality" of capitalism: monopolistic exploitation of consumers and workers, exploitation of the less-developed countries, unemployment, poverty, inflation, and stagflation. ${ }^{9}$

The required readings in this course consisted of three works by Lenin and materials from the 27th Congress of the Communist Party. In addition, pages from several other books were assigned. The titles of several of these books are revealing, including: Monopolistic Pricing, Large Business: The Way to Domination, Large and Small Business: Ties and Contradictions, The Rule of Monopolies as Factors of Deepening Contradictions of Modern Capitalism, and Evolution of Forms of the Monopolistic Trusts.

The third year in the required political economy sequence treated more practical aspects of managing a socialist economy (Table 2). In light of the subsequent events, it is ironic that the third and final course ends with topic 15 (acceleration of the social-economic development [of socialism] and the communist perspective).

The required readings for the course again included the works of Marx, Lenin, and Gorbachev; resolutions of the Central Committee of the Communist Party; and selections from the main textbooks. The recent party documents usually consisted of critiques of the mistakes of the previous Soviet regimes but never criticized the current regime. The additional readings were titled "Establishment of the Socialist Production Relations," "Stages in the Development of the Communist Mode of Production," and "All-Significant Stages of the Establishment and Development of the Communist Social-Economic Formation."

It was in this third course that the main textbooks diverged somewhat. The Rumyantsev textbook (1985) laid an extensive foundation for planning by examining the concept of property and its role in the formation of a socialist economy. The Tsagolov textbook (1973) concentrated on the principles of socialist planning themselves. Tsagolov was the head of political economy at Moscow State University, and not surprisingly, his book was emphasized most there.

\section{BEYOND THE PRINCIPLES COURSE: THE EMERGING CURRICULUM}

Alexeev, Gaddy, and Leitzel (1992) have characterized the Russians as "undecided on the path" of curriculum reform in economics. They quote A. R. Markov, assistant dean of the college of economics at MSU, as he describes several paths under consideration, only one of which follows the mainstream American route. However, a decision had already been made in 1989, with the blessing of the Gorbachev regime, to translate and publicly distribute a Western principles of economics book. This decision and the use of more advanced economics books 
in English have coincided with a decision to adopt the typical American structure of micro and macroeconomics, at least in the beginning course.

Not only has the introductory political economy course been reformed, so has the entire economics degree. The new undergraduate curriculum for a major in general economics is listed in Table 3 . The system of kafederi, or chairs, continues in the new curriculum. Some 15 separate chairs, or departments, have offerings in the new general economics curriculum. For example, the chair of industrial economics provides the course in economics of enterprises. The economics degree also has become an amalgam of economics and business administration courses. A few of the old courses simply have been given new titles. For example, Scientific Atheism has become History of Religion, an unusual requirement for an economics degree. The key test as to the true nature of the curriculum reform depends upon what is being taught under the rubric of each new title. Much of this may be like assigning a creationist to teach evolution. But, having said this, there can be no doubt that the new curriculum in Table 3 has a strikingly different look and feel from the previous courses in economics.

Gone is the Marxist-Leninist beginning course. Gone are the special seminars on Marx's Capital, the theory of imperialism, and the political economy of socialism. Gone are the state exams. It is relatively easy to substitute a standard Western

TABLE 3

New Undergraduate Curriculum in Economics: Required Courses for General Economics Specialization, Moscow State University, 1992

\begin{tabular}{lc}
\hline & $\begin{array}{c}\text { \# of months out } \\
\text { of the academic } \\
\text { Course }\end{array}$ \\
\hline Theory of general economics (principles of macro and microeconomics) \\
Theory of the world economy & 3 \\
Mathematics & 1 \\
Introduction to modeling economic and mathematical theory & 4 \\
Economic geography and regional economics & 1 \\
State regulation and planning of national economy & 1 \\
Economics of enterprises & 1 \\
Economics of agrarian sector & 1 \\
Economics of social sector & 1 \\
Environmental economics & 1 \\
Economics of foreign countries & 1 \\
Economic information & 1 \\
Accountancy and economic analysis & 2 \\
Currency circulation and credit & 1 \\
Finance & 1 \\
Introduction to management & 1 \\
Economic history of the former Soviet Union & 1 \\
History of economic thought & 2 \\
Polito-logics & 2 \\
Statistics & 1 \\
Demography & 2 \\
History of religion & 1 \\
Philosophy & 1 \\
\hline
\end{tabular}


title for each of the course titles in the listing. This was not true for the old curriculum.

\section{OBSTACLES TO CONTINUED CURRICULUM REFORM}

The academic revolution in Russian economics undoubtedly will continue for many years, but what are the prospects for continued progress? We examine five impediments facing reform in this section and look at favorable factors in the next.

Bureaucratic/organization difficulties. Historic rivalry between political economy and economic cybernetics and among the many kafederi may impede curriculum reform as each unit tries to stake claims to new turf. The current mixture of economics and business administration courses within the economics curriculum also may hinder the full development of an intensive degree in market economics. Separate degrees in economics and business administration are emerging, but attempts to meld a new curriculum with old academic structures may slow the transformation of the curriculum.

Another bureaucratic problem relates to finances. The Russian universities are being starved by slowly rising nominal budgets and rapid inflation. Indexing has not preserved real faculty salaries, and many professors have long resorted to moonlighting (tutoring, translating, consulting, etc.) to make ends meet. It is ironic that the faculty are induced to divert so much time from academics when the academe is so much in need of renewal.

Lack of adequate educational materials. Most of the old political economy publications belong in the "dust bin of history," but there simply are not enough Russian economists trained in market economics to develop new course materials. The best strategy for reform may be translations of the classics in market economics - as soon as possible. It is ironic, however, that perestroika has become an impediment to glasnost. Now that the Russians are finally free to purchase Western books and journals, many professors find it more difficult to buy them because of low real pay and the rapidly depreciating ruble. Meanwhile, the lack of educational materials will seriously impede the success of curriculum reform. ${ }^{10}$

Obsolete specific human capital. Professors who have devoted their most productive years to Marx, Lenin, and central planning now find their stock of specific human capital largely obsolete. In response to our postseminar evaluation questionnaire, many professors indicated that they had been fairly familiar with pure microeconomic theory. They also had some awareness of Keynesian economics, although its practical significance was lost in a centrally planned economy. Because of the Marxist-Leninist critique of international trade and finance as imperialism and the Soviet Union's official quest for self-sufficiency, however, the professors had been severely deprived in the area of international economics. Likewise, the Soviet system was devoid of banks as we know them and still is virtually a checkless economy, so most professors were eager to learn about the money supply and a fractional reserve banking system. Beyond that, they were fascinated by the application of theory to issues and policies- 
practical analysis that previously would have been dangerous in the Soviet Union. As Ailes and Rushing (1991) pointed out, instruction in MarxismLeninism was supposed to legitimatize the regime, not prepare students for economic analysis and decisionmaking.

There may be a positive side, however, to the quasi-scientific nature of political economy in Russia. Many professors who professed Marxism-Leninism did so only because it was demanded of them. Once they master the new economics, they may prove to be equally adept at explaining private enterprise and markets.

The socialist/central planning mindset. The decades of viewing economics through the lens of socialism and central planning has created a mindset among some economists that will be difficult to change. One question asked in our seminar was how we might go about measuring and aggregating indifference maps. Further discussion clarified that the questioner was interested in techniques to help central planners decide which goods to produce! Such notions as "markets are chaotic" and "speculators are evil" retain powerful holds on many economists in Russia. For example, some Russian seminar participants still questioned whether the Russian trade deficits were attributable to Western monopolistic pricing. There was also widespread concern about uncertainty and fraud associated with market activity, an attitude aggravated by the lack of enforceable commercial laws in Russia. The enthusiasm shown for market economics by the majority of Russian professors in our seminar was threatening to one or two established scholars who wanted more time devoted to criticisms of market economies. In a country that officially subscribed to the labor theory of value for so long, it seemed ironic that many Russians regarded natural resources as their only source of comparative advantage. Of course, this perspective stemmed from the export practices of the Communists rather than from Marxism. In the view of many Russian professors, however, the reliance on natural resources is both a blessing and a curse, because they feel that their economy will suffer the same kind of "exploitation" as developing countries.

Despite the occasional expressions of the old ideology in our seminar, most Russian professors needed little convincing that markets worked better than central command. In this sense, they reflected popular opinion in Russia. Opinion polling by Shiller, Boycko, and Korobov $(1991,1992)$ has shown that, in Russia, popular attitudes toward economic behavior are not substantially different from those in the United States. General attitudes-especially those of students-are not likely to impede the adoption of market economics, but the attitudes of some older political economy professors are significant obstacles to progress.

Political uncertainties. Understandably, economists and administrators who are leading the curriculum reform in Russia are reluctant to get too far out front of events. They fear that doing so could expose them later to retribution, should the political situation in Russia suddenly change.

More subtle inhibitors of academic revitalization related to political instability also exist. Under the Communists (particularly Stalin), it could be very dangerous to state certain facts precisely, to take a well-defined position on some 
economic matters, or to follow a logical process to a definite conclusion that might be disliked. This danger appears to have an effect on the way many Russian economics professors speak, write, and perhaps think. There is a strong tendency toward vagueness, uniformity, and ambiguity that stifles discussion, debate, and intellectual initiative.

In these turbulent times, some Russians also cling to their nationalistic pride as to an anchor. Consequently, foreign ideas are viewed suspiciously and are often criticized as inappropriate for a country as unique as Russia. Thus, political realities and uncertainties remain important obstacles to successful reform of the economics curriculum.

\section{FACILITATORS OF CONTINUED CURRICULUM REFORM}

For the following five reasons the prospects for reform of the Russian economic curriculum are not as bleak as our previous discussion might suggest.

Current direction from the top. The Yeltsin education officials and economists are strongly committed to reforming the economics curriculum in Russia. Because of the widespread view (even among Yeltsin's opponents) that it is impossible to return to the old system, we expect this political support for academic reform to continue.

At a dedication ceremony, the new rector of Moscow State University applauded the translation of the McConnell and Brue book and the incorporation of market economics in the curriculum. The glasnost-era dean of the College of Economics bluntly stated that the past focus only on Marx had been a mistake. These comments were not lost on the participants of the seminar in market economics who were in attendance. Russian professors are used to curriculum being dictated from above and seem willing to respond to such directives.

Nationwide economics requirement. The first-year Marxist-Leninist political economy course was required of all university students in the former Soviet Union. Because the new principles of economics course replaces the first-year political economy course, there will be wide dissemination of market economics throughout Russia.

Bright, well-prepared students. The high school curriculum in Russia contains more mathematics than does the American curriculum (Rushing 1994). University students, in particular, are well prepared in mathematics and are rapidly learning English. Therefore, some of the typical difficulties that American students face in the principles course-problems with graphical analysis and abstract reasoning - may be less of a problem in Russia. Students in Russia are now highly motivated to learn about market economics. They view this knowledge as being important in understanding the reforms in the economy, but also as crucial to their personal success in the new private enterprise economy. Many students are already engaged in entrepreneurial activity.

Core of economists familiar with market economics. Roughly one-tenth of Russian economics professors at Moscow State University have studied market economics abroad and more have quietly studied Western journals for years. In 
our 1992 seminar, questioners who interjected terms such as the Coase theorem and the Herfindahl index in their questions made it clear that several seminar participants had knowledge of formal microeconomics. These economists can give direction to the curriculum reform efforts.

Willingness to import textbooks and materials. Intense efforts are underway to translate Western articles and textbooks, although progress is slow by American standards. Western publishers have practically given away publication rights, because Russian publishers have so much trouble obtaining dollars to pay royalties. The United States Information Agency and the Agency for International Development as well as the European Community are supporting technical assistance missions by Western academicians to help work on economic and business curricula in all of the republics of the former Soviet Union.

Of course, using a standard American textbook in the beginning economics class has its limitations. Many parts of the book are institutionally specific to the United States. For example, the chapter on the problem of American agricultural surpluses is hardly relevant to students in a country with stagnant state agricultural production. Efforts to adapt the American materials, through rewriting examples for the Russian audience, will need to be implemented as soon as possible.

\section{CONCLUSIONS}

On balance, we believe that the reform of the economics curriculum in Russia will take considerable time. This reform will be accomplished in reality long after it has occurred in the university catalogs. Yet, in many respects, the curriculum reform is less daunting than the reform of the Russian economy itself. In both cases, there appears little chance of completely returning to the old ways. The old political economy curriculum in Russia was the official curriculum of the Communist Party and the party was the disciplining device keeping it in place. With the demise of the party has come the abandonment of the old curriculum, particularly in the beginning course. The remaining question about the reform of the curriculum is how long it will take, not whether it will survive. The widespread availability of Western economic ideas now in the Russian language greatly reduces the likelihood of a return to anything resembling the old MarxistLeninist curriculum.

\section{NOTES}

1. The third instructor in the seminar was William B. Walstad, professor of economics, University of Nebraska-Lincoln.

2. For example, translators had trouble recognizing the distinction between changes in demand and changes in quantity demanded, but some of the professors who were already familiar with English terminology would usually speak up and correct these mistakes. Therefore, we feel that the translation was far better than that accorded Samuelson's textbook in 1966. See Gershenkron (1978).

3. Paul Samuelson's book was translated into Russian in the 1960 s, but was available only for "research" purposes. Other American principles texts that have been translated into Russian and are widely available include Heyne (1987) and Dolan and Lindsey (1991). One or two other principles texts are now being translated, as are intermediate-level American texts. Interest in market economics is so strong in Moscow that copies of the McConnell-Brue text were being sold by street vendors immediately after printing at prices as high as four times the publisher's list price. 
4. The College of Economics has more than 1,200 applicants per year and one-third of the applicants were ranked first, second, or third in their high school graduating class. Only about 250 applicants are accepted per year. The high labor intensity common in most Russian activities is illustrated by the college's faculty/student ratio of $1 / 5$.

5. Kantorovich was one of the early formulators of linear programming. For this work, he shared the Nobel Prize in economics with American Tjalling Koopmans in 1975.

6. There is also a degree in social and economic planning granted by the College of Economics, although recipients were referred to as planners rather than economists.

7. Outside of our 1992 seminar, one of the authors was given a lapel pin symbolizing the SOFE kafederi. Not fully aware of the internal politics involved, he wore the SOFE pin to the seminar the next day. A member of the political economy faculty immediately reacted by presenting him with the rival pin, and diplomacy seemed to dictate that both pins be worn for the remainder of the seminar.

8. The cybernetics curriculum for a 1984 graduate did not include courses $6,7,13,28,30$, and 31 in Table 1. In addition, the cybernetics major took public economics, operations research, cybernetics, multivariate statistics, finite mathematics, management theory, and eight courses on optimization models.

9. The same emphasis characterized the History of Economic Theories course that concentrated on Jevons, Marshall, Bohm-Bawerk, Chamberlin, Commons, Galbraith, Joan Robinson, and Keynes. Much time was spent on a critique of the so-called anti-Marxists, Mises and Hayek. Practically no time was spent on systematic explanation of analyses like the Keynesian model. There was little mention of monetarists, supply-side, rational expectations, real business cycle, new classical, post-Keynesian, and new Keynesian economics, and this neglect may explain the eagerness of our seminar participants to hear about these modern developments in economic thought.

10. The scarcity of educational capital became apparent in our seminar as the participants meticulously copied every word in painstakingly small print so as to conserve paper. Overhead transparencies were also regarded with awe, and we left our set there. Even library holdings for research are slim. We looked at a doctoral dissertation on market theories of land rents completed in 1992 that had only about a dozen Western references, mostly dating from 1910 to 1960 and only one from the 1980s. The Moscow State University branch campus at Ulyanovsk had only one economics book in its library until 1993. On a more positive note, many of the materials developed by economic mathematicians can easily be modified to apply to the new market economics curriculum. Furthermore, translated economics books have increasingly become available to students in the past few years.

\section{REFERENCES}

Ailes, C. P., and F. W. Rushing. 1991. Soviet math and science educational reforms during perestroika. Technology in Society 13:109-22.

Alexeev, M., C. Gaddy, and J. Leitzel. 1992. Economics in the former Soviet Union. Journal of Economic Perspectives 6 (Spring): 137-48.

Blodgett, R., and M. Schnitzer. 1965. Soviet teaching and research in economics. Washington, D.C.: Government Printing Office.

Dolan, E. G., and D. E. Lindsey. 1991. Economics, 6th ed. Orlando: Dryden.

Heyne, P. 1987. The economic way of thinking, 5th ed. New York: Macmillan.

Judy, R. 1960. Economics at Moscow State University. Cambridge: Russian Research Center, Harvard University.

Gerschenkron, A. 1978. Samuelson in Soviet Russia: A report. Journal of Economic Literature 16 (June): 560-73.

McConnell, C. R., and S. L. Brue. 1990. Economics, 11th ed. New York: McGraw-Hill.

Rumyantsev, A. 1985. Political economy: A textbook for economic colleges and departments, 6th ed Moscow: Politizdat.

Rushing, F. W. 1994. The changing face of economics instruction in Russia. In An international perspective on economic education, ed. W. B. Walstad, Boston: Kluwer, 233-54.

Shiller, R. J., M. Boycko, and V. Korobov. 1991. Popular attitudes toward free markets: The Soviet Union and the United States compared. American Economic Review 81 (June): 385-400.

- 1992. Hunting for Homo Sovieticus: Situational versus attitudinal factors in economic behavior. Brookings Papers on Economic Activity (1): 127-94.

Sutela, P. 1991. Economic thought and economic reform in the Soviet Union. Cambridge: Cambridge University Press.

Tsagolov, N. A., ed. 1973. A course in political economy, 3d ed. Moscow: Ekonomika. 